OPRE/TEC

MACM ILLAN

Updating

for

Business

\title{
Training and Coaching Skills
}

\section{Tutor Guide}

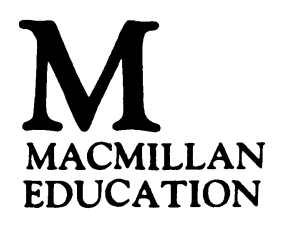




\section{Crown copyright 1986}

Published by permission of the Controller of Her Majesty's Stationery Office.

This work was produced under an Open Tech contract with the Manpower Services Commission. The views expressed are those of the authors, and do not necessarily reflect those of the MSC, or any other Government Department.

All rights reserved. No reproduction, copy or transmission of this publication may be made without written permission.

No paragraph of this publication may be reproduced, copied or transmitted save with written permission or in accordance with the provisions of the Copyright Act 1956 (as amended).

Any person who does any unauthorised act in relation to this publication may be liable to criminal prosecution and civil claims for damages.

First published 1986

Published by

MACMILLAN EDUCATION LTD

Houndmills, Basingstoke, Hampshire RG21 2XS

and London

Companies and representatives

throughout the world

Typeset by Communitype, Leicester

ISBN 978-0-333-43113-9 ISBN 978-1-349-09173-7 (eBook)

DOI 10.1007/978-1-349-09173-7 


\section{Contents}

PART 1 General Information and Guidance

1 Introduction

The Units and the Materials; BTEC Approval and Awards

2 Preparing to Run the Course

3 The Open Learning Student

4 Open Learning Tutorials

5 Tutor Review Exercises

6 Feedback on the Materials and Their Use

7 The Personal Study Plan

PART 2 Information Relating to this Unit 